\title{
Rozhovor s Vilémem Heroldem
}

Úvodem ke vzpomínání na mého dávného přítele a dobrého kolegu Milana Mráze, s nímž jsme se znali více než 40 let, od konce 60-tých let, bych řekl, že jeho úmrtí přišlo poněkud nečekaně a všechny nás velmi zaskočilo, i když asi zaskočit nemělo, nebot' Milan v poslední době už na tom byl velmi špatně a přinejmenším ti, kdo k němu měli nejblíže museli vidět, že jeho síly odcházejí.

Pane docente, vy jste znal Milana Mráze dlouhá léta, konkrétně od konce šedesátých let jste právě řekl. To znamená, že $V y$ jste byl na Filosofickém ústavu již nějakou dobu předtím, než on přišel. Generačně i jinak tedy představujete pohled, ze kterého čtenáři, ale ani většina $z$ nás, kteří jsme $s$ Milanem Mrázem úzce spolupracovali, jej nemohla znát. Byl pro Vás spíš př́telem, nebo spolupracovníkem? Ty role tam přece byly obě...

To by pro mne bylo velice obtížné rozlišit, byli jsme jak dobří přátelé, tak vynikající kolegové. Poznali jsme se zprostředkovanou náhodou: koncem šedesátých let se v Ústavu rozběhl seminář pro dějiny středověké filosofie iniciovaný Stanislavem Sousedíkem a Robertem Kalivodou. Filosofický ústav tehdy sídlil Na př́kopě 29 a v tamní 
studovně se seminář scházel nad přednáškami dr. Špirce, dr. Šmelhause a tehdy dr. Stanislava Sousedíka; já sám jsem tam tehdy měl taková spíše praktická cvičení z latinské paleografie. A právě na tento seminář začal docházet tehdy ještě posluchač Filosofické fakulty, byt' vzhledem k politickým potížím již letitý, Milan Mráz.

Chystali jsme tenkrát zvláštní mediavelistické číslo Filosofického časopisu a Stanislav Sousedík přišel s návrhem, aby v čísle vyšel překlad Porfyriova Úvodu k Aristotelovým Kategoriím. Překlad pořídil Milan Mráz a touto cestou se uvedl na onom semináři. Při té př́ležitosti jsme se vlastně poznali a musím říci, že to bylo osudové setkání jak přátelské, tak kolegiální od samého začátku.

Právě jste vzpomenul, jak jste se s Milanem Mrázem seznámili, jaká byla geneze Vašeho přátelství. Říká se, že první, spontánní myšlenka je rozhodující - když se tedy řekne „Milan Mráz“, co Vás právě ted' napadne?

Na Milanu Mrázovi jsem si cenil několika věcí. Profesně jsem obdivoval jeho vynikající znalosti klasické filologie, staré řečtiny - a pokud jde o můj obor, i latiny. Milan Mráz převážnou část svého života věnoval antické filosofii. Ale to neznamenalo, že by si nebyl vědom přssahů antiky do filosofie středověké, to koneckonců je zřejmé i z jeho překladu Porfyriova Úvodu, který byl později na středověkých universitách používán jako základní příručka k pochopení Aristotelovy filosofie. Druhá věc, kterou jsem 
obdivoval, byla vynikající pamět' - nejen fakta z odborného života, ale i detaily z osobního, ty drobnosti, které obklopují neustále každého z nás.

Možná bych zde mohl uvést dva mediavelistické projekty, na nichž jsme spolupracovali zvláště úzce. První byl při příležitosti jubilea Milíče z Kroměříže, kterého si všimlo Unesco a očekávalo nějakou důstojnou oslavu od Ústavu. Navrhli jsme vydat 3 dosud nevydané synodní řeči, byl na to tehdy velmi krátký čas necelého roku. Tak jsme si dali dohromady rukopisy, kde je zachován opis tří Milíčových řečí synodních, a ty jsme připravili k edici. Paleografickou stránku jsem měl na starosti já, Milan byl především tím výtečným klasickým fillologem; dohromady jsme k tomu připravili úvod a v roce 1974 jsme tyto tři řeči skutečně s povolením ministerstva kultury vydali. Vzpomínám, jak jsem jezdil k Milanovi na chatu k Mladé Boleslavi a tam jsme pracovali na kolaci všech těch rukopisů. Zejména $\mathrm{v}$ prŕípadě řeči Sacerdotes contempserunt bylo těch rukopisů mnoho - třicet - takže nám odborníci později nechtěli věřit, že jsme těch třicet exemplářů pečlivě pročetli, zaznamenali příslušné varianty a připravili k vydání.

Právě jste narazil na další důležitou stránku odborného či snad i širšího profilu Milana Mráze, jeho porozumění střredověké recepci antické tradice. Nesmíme zapomínat, že stál jako významná postava za Oddělením pro starší 
evropskou filosofii - nevím tedy přesně, zda př́mo za jejím vznikem, nebo snad výrazným posunem?

Dalo by se říci, že se Milan velmi zasloužil o vznik Oddělení pro dějiny starší české a evropské filosofie Filosofického ústavu po jeho znovuobnově po roce 89 . Oddělení vzniklo jako nástupnická pracovní skupina z Oddělení dějin filosofie starého Filosofického ústavu - tam to bylo oddělení velice utiskované a až na malé výjimky pramálo podporované - a vzhledem $\mathrm{k}$ tomu, že se Milan záhy stal ředitelem obnoveného Filosofického ústavu a poté také vedoucím tohoto oddělení, tak také měl značný vliv na jeho formování. Dá se říci, že orientace na antickou filosofii byla pro toto oddělení velice významná. Milan Mráz dlouho určoval personální profil oddělení i jeho zaměření. Je nespornou zásluhou Milana Mráze, že se toto oddělení v rámci ústavu tak dobře rozvíjelo a že $v$ něm pracuje řada významných badatelů.

To je také věc i v evropském či mezinárodním měřítku relativně neobvyklá, že $v$ rámci jednoho oddělení je spojeno bádání o antice a středověku. Nejpozději po roce 1960 bývají tyto dvě oblasti studovány obvykle separátně. Máte pocit, že vaše osobní přátelství se na tom $\mathrm{v}$ počátcích podepsalo, že naše oddělení dodnes vlastně pracuje tímto způsobem?

Já myslím, že to je nesporné. Ve druhém př́ípadě naší již zmiňované spolupráce, která se rozvinula nad dědictvím 
Jenka Václavova $\mathrm{z}$ Prahy, šlo ještě více než v př́padě Milíčově o poznání aristotelského dědictví. Jenek Václavův, jenž byl jmenován Karlem IV. jako člen mistrovské Karlovy koleje pražské university, zanechal čtyři komentáře k Aristotelovým spisům. Právě tyto komentáře jsme si tehdy dali za úkol prozkoumat. Sám jsem se věnoval spisu věnovanému Aristotelově Politice a Milan Mráz zkoumal spisy pojednávající o De generatione et corruptione a komentár̆ k De caelo et mundo. Objevy, které jsme měli při této př́ležitosti možnost společně učinit, byly velmi zajímavé, takže i zde bylo ono spojení antické s šedověké filosofie naprosto jednoznačné a možná že i to vedlo k tomu, že jsme později nechtěli tyto oblasti oddělovat.

Tak v současné době se zdá, že tato tendence plodně pokračuje, naše colloquia ukazují, že to je inspirace pro obě strany velmi zajímavá. Myslím si, že to byla výborná myšlenka a že se tím dosáhlo propojení, které možná jinde ve světě chybí. Navázal bych zde další otázkou, rovněž na Vaše slova, že se Milan Mráz jednoho dne stal ředitelem filosofického ústavu. Ovšem $V y$ jste jej po určité době v té funkci nahradil - vlastně jste se, dá se říci, vystř́ídali: $V y$ jste byl vedoucím toho Oddělení starší filosofie, Milan nějakou dobu také. Změnilo to nějak váš vztah, že jste byli vzájemně tu ten, tu zas onen stř́davě v nadř́zené a podřŕzené posici? 
Já jsem se už v závěru roku 89 dostal do vedení akademie, byl jsem od roku 90 do roku 92 členem předsednictva, pak do roku 2001 jsem měl $\mathrm{v}$ akademii na starosti všechny humanitní a společenské vědy. V roce 2001 skončilo Milanu Mrázovi jeho druhé ředitelské období, cože je na Filosofickém ústavu maximum, a tak jsem se stal ředitelem ústavu já. Já myslím, že jsme nikdy jeden vůči druhému neměli pocit podř́zenosti nebo nadř́zzenosti; Milan Mráz byl skvělým ředitelem tohoto pracoviště, byl i skvělým šéfem zmíněného oddělení, a vlastně až do posledních let a měsíců jeho života jsme spolupracovali naprosto ideálním způsobem. Považuji toto řízení osudu za velice př́znivé, za takový dar od Pánaboha, mohu-li to tak vyjádřit.

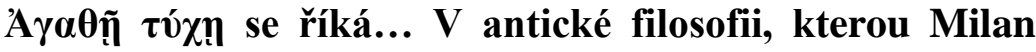
Mráz po většinu života pěstoval primárně, platí, že myslitel - a filosof zvláště - svědčí také svým osobním životem a svým osobním profilem za své myšlenky. Tedy že je zde osobní odpovědnost, ̌̌ekové se zajímali, kolika let se dotyčný myslitel dožívá, v jakém je zdravotním stavu a jak vypadá jeho rodinné prostředí, jak si dokáže uspořádat svoje osobní záležitosti. A tohle všechno nějak patř́ ke konceptu řecké filosofie. Není to jen theoretická disciplína, je to komplexní disciplína. Vy jste tu soukromou stránku života Milana Mráze znal nepochybně nejlépe z nás. Zdá se vám, že se v soukromém životě nějakým výrazným způsobem projevoval jako 
filosof, který naplňuje onen harmonický obraz myslitele, který dělá věci prostě tak, jak je zapotř̌ebí ... ?

Ano, Milan Mráz se věnoval Aristotelovi s obdivuhodným úsilím po celý život. Když nastoupil do ústavu, tak nejprve přeložil Topiky, pak jeho spis $O$ sofistických dỉkazech, a na těch důkladných revizích a nových překladech pracoval do posledních dnů života. Také onen zmíněný Porfyriův Úvod k aristotelským Kategoriím (Eisagógé) připravil pro knižní vydání, jež se připravuje v nakladatelství OIKOYMENH.

Já myslím, že Milan opravdu naplňoval ideálním způsobem takový ten požadavek svého milovaného autora. Aristotelův takový praktický př́stup k životu se v Milanově životě odrážel velice dobře, jeho ideál člověka moudrého, tj. nejen znalého, ale opravdu moudrého, Milan převáděl na praktické rovině - prakticky každodenně - obdivoval jsem jeho rozhodnutí, která učinil, někdy ne právě v lehkých situacích svého života. A obdivoval jsem koneckonců i to, co stačil za svi̊j život vykonat, protože uvědomíme-li si, co bylo zanecháno dalším generacím vědců v podmínkách, které měl $\mathrm{k}$ disposici, tak je to naprosto úctyhodné.

Tak ted' jste narazil na jednu z věcí, kterou my mladší možná máme tendenci vidět trochu jinak. Tato stránka jeho osobnosti mne vždy na jednu stranu fascinovala, na druhou stranu jsem si - možná trochu mladicky nevděčně - vždy kladl otázku, zda taková praktická angažovanost byla $z$ jeho strany rozumná volba. Já jsem zažil Milana 
Mráze ještě, jako řekněme končící student a právě on mi tehdy otevřel cestu $k$ Aristotelovi v originále; přece jen jsem byl vždy více platonikem (což bylo jistě způsobeno také tehdejším jednoznačným upřednostněním Platóna na fakultě a snad i vůbec $v$ Čechách) a ono zásadní setkání $\mathbf{s}$ Aristotelem bylo, alespoň $\mathbf{v}$ mém př́padě, spojeno jednoznačně s Milanem Mrázem. A právě proto, že jsem se již tehdy měl možnost $\mathrm{z}$ bezprostř̌ední blízkosti přesvědčit, že nikdo jiný zde aristotelská studia $s$ touto erudicí a soustavností nepěstuje a pěstovat nemůže, tak se mi později jako začínajícímu badateli ústavu tím více zdálo, že jeho aktuální úřrední zaneprázdněností trpí ona práce pro futuro - tedy zejména ony překlady, kterých by jistě býval mohl stihnout mnohem více. Na druhou stranu je pravda, že touto svou volbou dokázal nás, řadové badatele, doslova na dlouhá léta uchránit před narůstajícím nátlakem zvenčí - po dobu jeho ředitelování jsme neměli ponětí o oněch existenčních potížích akademického bádání, kterým jinde již čelili v plné hrůze jejich hloubky. Neměl jste někdy pocit, že je jeho talentu škoda, že vstoupil příliš daleko na pomíjivou půdu polis a nezbývalo mu tak času i sil na ne-li věčnou, pak jistě trvalejší půdu akademie? Nezazlíval jste mu to trochu jako osobní prrítel, který si jeho schopností a možností musel být vědom nejlépe ze všech? 
Já myslím, že právě Vaše slova jsou potvrzením toho, co jsem se před chvílí pokusil ve vztahu k Milanovi neuměle formulovat, totiž právě onoho spojení zájmu o celek a zájmu o vědu. Tyto dvě věci od sebe nelze oddělovat, at' člověk dělá, co chce, vždy jej to určitým způsobem dožene a donutí se zabývat. Mne to nikdy takto formulováno vlastně nenapadlo, ale tak jak jste to velmi hezky vyjádřil, tak je to, myslím, velmi dobrým potvrzením Milanova úspěchu v tom, co se my všichni nějak pokoušíme dát dohromady, úspěchu ve spojení vědy a praktického života, protože jedno bez druhého nemůže být.

Pomalu se chýlíme ke konci, pane docente, než položím poslední otázku, tak Vám jménem našich čtenářů děkuji za milou a otevřenou vzpomínku na pro mnohé $z$ nás společného - a výjimečného - kolegu a přítele. Nyní k závěrečné otázce: jsme malá kultura, malá země. Národ mluvící jazykem, do kterého je třeba překládat třeba již jen $\mathrm{z}$ toho důvodu, abychom se intelektuálně udrželi ve srovnání s velkými národy a velkými kulturami. Samozřejmě je tedy potřeba převádět do češtiny ony věčné texty zakládající Evropu etc., a Milan Mráz v tomto ohledu udělal veliký kus práce. Ovšem právě proto, že jsme malá kultura a malý národ, tak takováto jednou odvedená práce je počinem na dlouhá léta, mnohem trvalejším, než např. v Německu nebo Británii, kde mají překladů více a neustále se tam na nich pracuje. Milana 
Mráze proto jakožto překladatele budou znát ještě generace a generace badatelů i čtenářů $z$ laické veřejnosti typu např. gymnasiálního čtenářstva etc.

Tito budoucí čtenáři již nebudou mít s Milanem Mrázem žádný osobní kontakt, budou jej znát jako pouhé jméno z minulosti, a jeho práci uvidí zcela odtrženou od jeho osobnosti. Máte pocit, pane docente, že právě pro tyto budoucí čtenáře byste dokázal zformulovat či popsat určité rysy Mrázovy osobnosti, které by každý, kdo se s jeho dílem setká, měl znát?

Práce na překladech klasických textı̊, zvláště pak na takových, jako jsou spisy Aristotelovy, je práce nevděčná, ale s nárokem na dlouhou užitečnost. Je to svým způsobem práce, která prřkonává život člověka. Chtěl bych věřit, že když ničím jiným, tak alespoň prostřednictvím těchto překladů, které odkázal české kulturní veřejnosti, bude Milan Mráz ještě velmi dlouho a tímto způsobem i aktivně mezi námi žít. 